\title{
SATELLITE REMOTE SENSING OF VATNAJÖKULL, ICELAND
}

\author{
by
}

Richard S. Williams Jr

(U.S. Geological Survey, 927 National Center, Reston, VA 22092, U.S.A.)

\begin{abstract}
Iceland's largest ice cap, Vatnajökull, has been the test site for a series of airborne and satellite remote-sensing studies since 1966. Various types of image data acquired by the Landsat Multispectral Scanner (MSS) and the Seasat Synthetic Aperture Radar (SAR) are assessed for their value to glaciological studies of Vatnajökull. A low Sun angle winter 1973 MSS band 7 Landsat image of Vatnajökull provides information about the distribution and size of subglacial volcanic calderas, cauldron subsidence caused by subglacial geothermal and (or) intrusive volcanic activity, and delineation of the probable position of surface ice divides. Two types of multi-spectral digital enhancements were applied to a late summer 1973 MSS image of Vatnajökull. The first type was used to prepare a planimetric base map showing the location of the principal surface features and an inventory of 38 named outlet glaciers, one internal ice cap (Öraefajökull), and two detached glaciers which comprise this complex ice cap, and to measure its area $\left(8300 \mathrm{~km}^{2}\right)$. The second type provides information about the position of the snow line at the approximate end of the 1973 melt season, the areas encompassed by the ice facies of the ablation area and the slush zone and wet-snow facies/percolation facies of the accumulation area. More information about the surface morphology of Vatnajökull was available from the low Sun angle winter and the digitally enhanced summer Landsat image of the ice cap than from the Seasat SAR image.
\end{abstract}

\section{INTRODUCTION}

Iceland's largest ice cap, Vatnajökull (Figs 1 and 2A), has been the focal point for a series of volcanological and glaciological airborne and satellite remote-sensing studies during the past 20 years. In the late 1960s and early 1970s three aerial thermographic surveys of known or suggested geothermal and volcanic areas within and peripheral to the ice cap were conducted (Friedman and others 1969, 1972), including the high-temperature geothermal area (Hveradalur) and volcanic features associated with the calderas at Kverkfjöll on the north-central margin of Vatnajökull. The knowledge gained from these surveys provided the scientific impetus for a succession of satellite remote-sensing experiments on Vatnajökull, beginning in 1973 with the first usable Landsat Multispectral Scanner (MSS) images. Research with Landsat data was initially directed at achieving a better understanding of the subglacial geomorphology and regional tectonic setting of the ice cap (Thorarinsson and others 1974); subsequent research has focused on glaciological studies (Williams 1983[a], 1986). Only limited analysis has been done with Seasat Synthetic Aperture Radar (SAR) images of Vatnajökull.

Vatnajökull is situated in south-eastern Iceland. It has an area of $8300 \mathrm{~km}^{2}$, according to measurements made from the 22 September 1973 Landsat image (Williams 1983[a]), or $8 \%$ of the area of Iceland $(73.7 \%$ of the area covered by

Author's note: The Icelandic letters, thorn (b), eth (ð), and $(æ)$ are used on all figures and in Table I. In the text, however, thorn, eth, and $æ$ are transliterated to th, $d$, and ae, respectively. Diacritics over Icelandic vowels are retained in both figures and text.

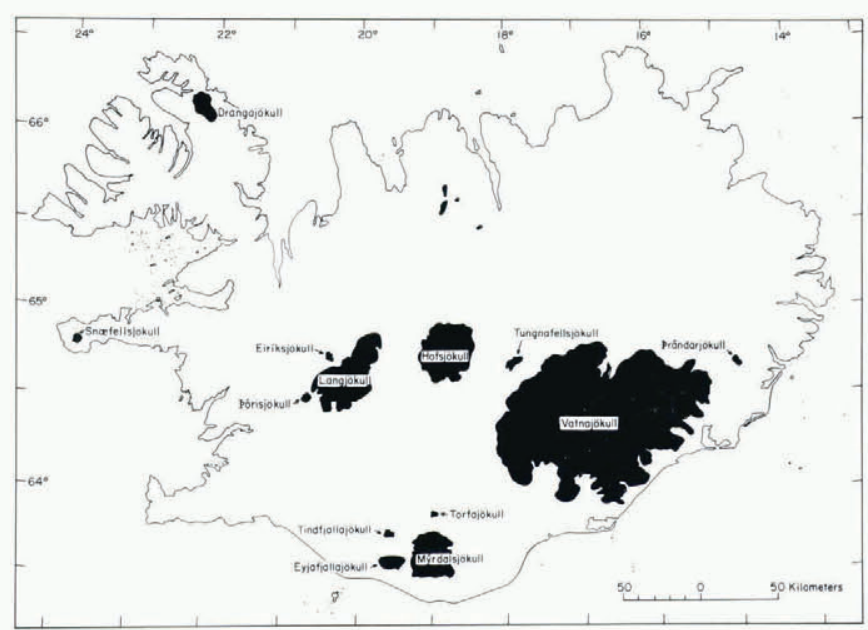

Fig.1. Index map (after Williams 1983[a]) of the 13 principal ice caps of Iceland. Base map modified from Rikisútgáfa Námsbóka, Reykjavik (no date).

glaciers (Björnsson 1980[a])). It has an estimated volume of $3520 \mathrm{~km}^{3}$ (Bauer 1955, Sigbjarnarson 1971). Although Vatnajökull appears to be simply a single large ice cap, in reality it is dynamically complex, the result of the coalescence of several independent foci of ice accumulation centered on subglacial volcanic highs. Emanating from this $8300 \mathrm{~km}^{2}$ composite ice cap are 38 named outlet glaciers (Table I; Fig.2A, B), each with its own physical and flow characteristics. There may be at least as many additional unnamed outlet glaciers, if all the various protruberances around its margin are included (Figs $2 \mathrm{~A}, \mathrm{~B}$, and 3 ). West of a line between the western edge of Kverkfjöll and the eastern margin of Sídujökull, Vatnajökull straddles the northern part of the Eastern and the southern part of the Northern Volcanic Zones of active volcanism, including the dormant subglacial volcano at Thórdarhyrna which last erupted in 1903 (Thorarinsson and Saemundsson 1980), and intrusive and extrusive volcanic and geothermal activity associated with the calderas at Grimsvötn and Kverkf jöll. Grímsvötn has had a long history of volcanic activity (sporadic documentation since the sixteenth century), with two eruptions in this century (1934 and 1983); there have been seven (or eight?) known volcanic eruptions from the Kverkfjöll area during the past 500 years (Thorarinsson and Saemundsson 1980). The south-eastern part of Vatnajökull is dominated by the ice center and large composite volcano, Öraefajökull, which has the highest elevation in Iceland at $2119 \mathrm{~m}$; two historic eruptions took place in 1362 and 1727 , respectively (Iceland Geodetic Survey 1979, Thorarinsson and Saemundsson 1980). Volcanic eruptions from Kverkfjöll and Öraefajökull cause jökulhlaups, or glacier outburst floods, down the valley of Jökulsá á Fjöllum to the north and across the eastern part of the outwash plain of Skeidarársandur on the south, respectively. Grimsvötn is also the source of more periodic jökulhlaups (Rist 1955), following penetration of the ice dam on the east side of the 

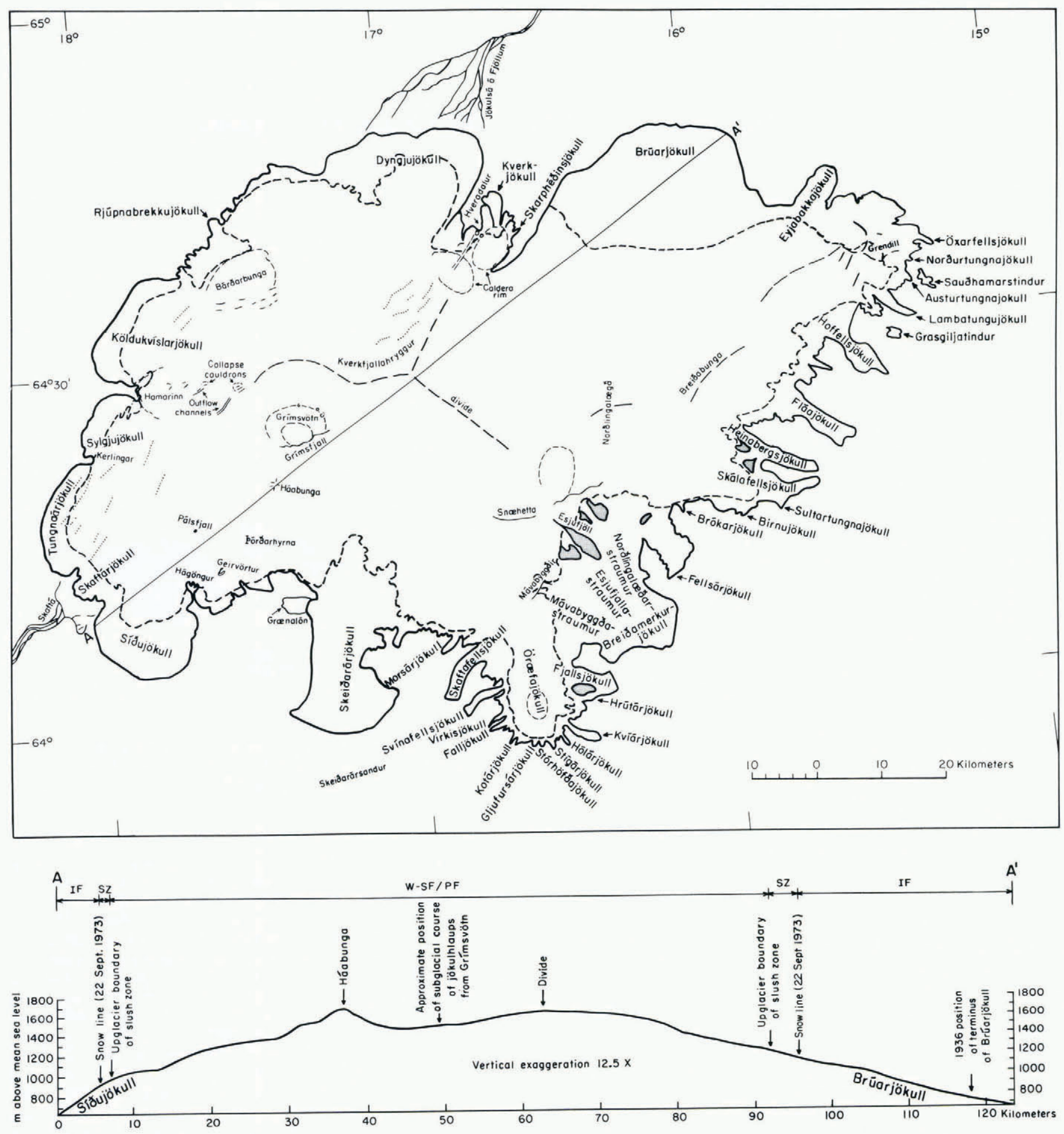

Fig.2A. Map of Vatnajökull, Iceland, showing the 38 named outlet glaciers, one interior ice cap (Öraefajökull), and two detached glaciers, and principal morphological features of the ice-cap surface, such as calderas (short-dashed lines), collapse cauldrons, surface lineations (dotted lines), and the probable positions of surface ice divides (long-dashed lines) derived from Figs 3, 4, and 5 . Geographic place-names are from published maps and articles (see Table I). The transient snow line on 22 September 1973 is shown by a heavy dashed line. The stippled areas are nunataks. The portrayal of the glacial headwaters of Jökulsá á Fjöllum and Skaftá are derived from the third edition of the 1:500000 scale Touring Map of Iceland published by the Iceland Geodetic Survey (1984).

B. Cross-section (12.5× vertical exaggeration) along line $\mathrm{A}^{-\mathrm{A}^{\prime}}$ north-east across Vatnajökull from the terminus of Sidujökull to the terminus of Brúarjökull $(123.5 \mathrm{~km})$ showing the altitudinal positions of the transient snow line and the up-glacier boundary of the slush zone on 22 September 1973 (derived from Fig.5). The ice facies (IF) of the ablation area, and the slush zone (SZ) and wet-snow facies (W-SF)/percolation facies (PF) of the accumulation area are also shown. The position of the surface ice divide is derived from Figs 3 and 4 . The probable subglacial course of flood water from the March 1972 jökulhlaup from Grimsvötn (Thorarinsson and others 1974) is derived from Fig.3 (series of shallow depressions forming a chain east to south-south-east of Grimsvötn). Tómasson (1975) and Björnsson (1975) also showed the subglacial course of the 1972 jökulhlaup. Topographic elevations along $\mathrm{A}-\mathrm{A}^{\prime}$ derived from 1:250000 scale Adalkort (General) maps of Iceland, Iceland Geodetic Survey: Sheet 5 (1978), Sheet 6 (1973), Sheet 8 (1976), and Sheet 9 (1971). 


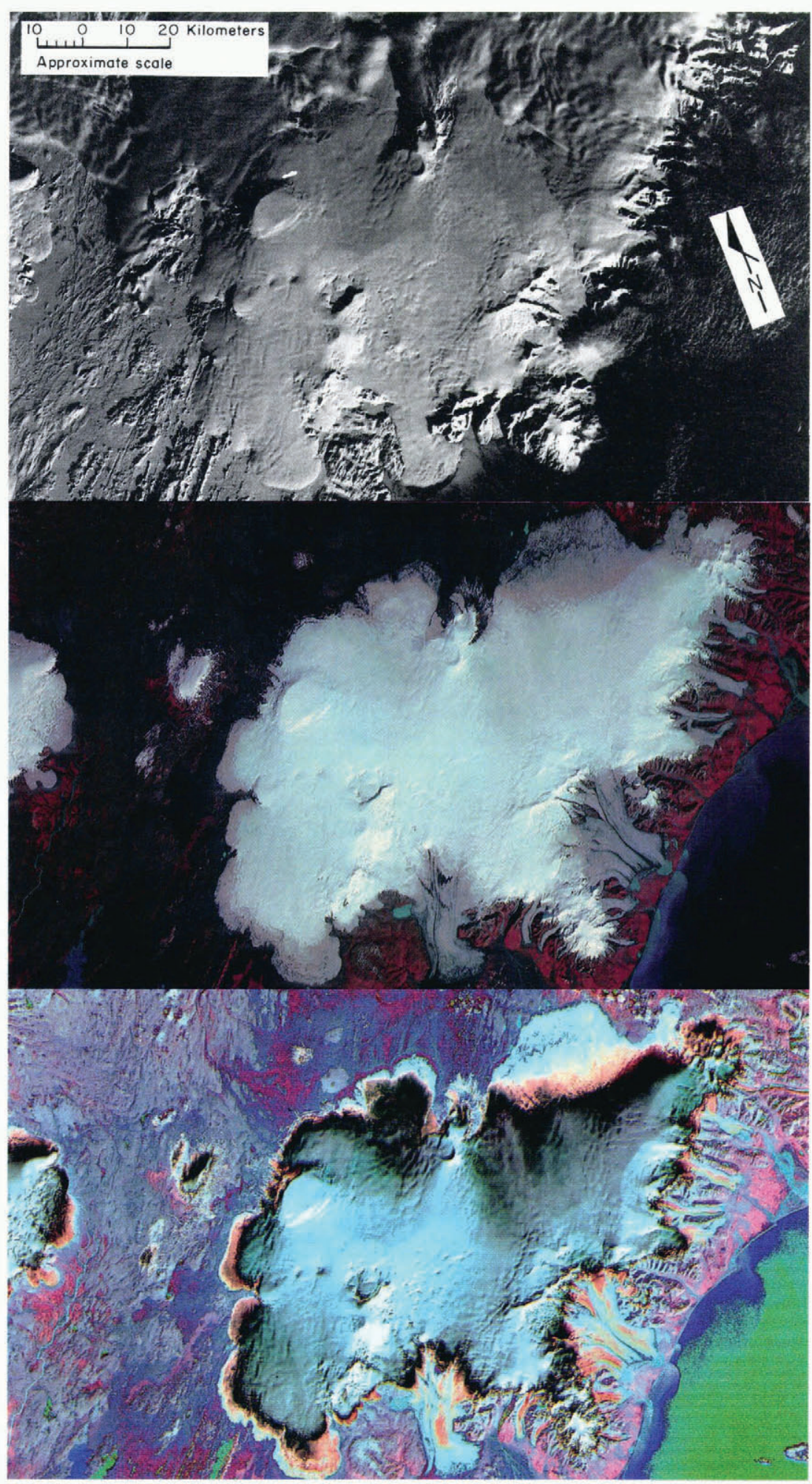

Fig.3. Conventionally processed, low Sun angle $\left(7^{\circ}\right)$ Landsat 1 MSS image (1192-12084, band 7 ; 31 January 1973), showing detailed surface morphology on Vatnajökull (see Fig.2). (Image by courtesy of EROS Data Center, US Geological Survey.)

Fig.4. Digitally enhanced Landsat 1 MSS false-color composite image (1426-12070, bands 4, 5, and 7; 22 September 1973), showing the principal morphological features on the surface of Vatnajökull (see Fig.2). (Custom digital image-processing by courtesy of Lincoln Perry, EROS Data Center, US Geological Survey.)

Fig.5. Digitally enhanced Landsat 1 MSS false-color composite image (1426-12070), bands 4, 5, and 7; 22 September 1973), showing differences in spectral reflectance of the various facies in the ablation and accumulation areas on the surface of Vatnajökull at the approximate end of the 1973 melt season. (Digital image processing by courtesy of Michael J. Abrams, Jet Propulsion Laboratory, California Institute of Technology.) 
TABLE I. NAMED OUTLET AND DETACHED GLACIERS OF VATNAJÖKULL. ${ }^{1}$ SEE FIG. 2 FOR GEOGRAPHIC LOCATIONS OF EACH GLACIER. ALTERNATIVE NAMES WHICH APPEAR ON SOME MAPS ARE GIVEN IN THE FOOTNOTES

Number
1
2
3
4
5
6
7
8
9
10
11
12
13
14
15
16
17
18
19
20
21
22

Name of outlet glacie
Skeiðarárjökull ${ }^{2}$
Síðujökull $^{3}$
Skaftárjökull $^{3}$
Tungnaárjökull $^{3}$
Sylgjujökull
Köldukvislarjökull
Rjúpnabrekkujökull
Dyngjujökull
Kverkjökull
Skarphéoinsjökull
Brúarjökull
Eyjabakkajökull
Öxarfellsjökull
Norourtungnajökull
Austurtungnajökull
Lambatungujökull
Hoffellsjökull
Fláajökull
Heinabergsjökull
Skálafellsjökull
Sultartungnajökull ${ }^{6}$
Birnujökull

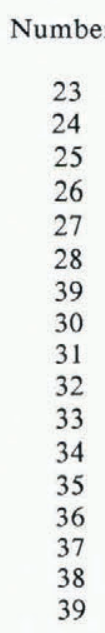

4
Name of outlet glacier

\author{
Brókarjökull \\ Fellsár jökull ${ }^{7}$ \\ Breiðamerkurjökull ${ }^{8}$ \\ Fjallsjökull \\ Hrútárjökull \\ Kvíárjökull \\ Hólárjökull \\ Stigárjökull \\ Stórhöf ðajökull \\ Gljüfursárjökull \\ Kotárjökull \\ Falljökull \\ Virkisjökull \\ Svinafellsjökull \\ Skaf tafells jökull \\ Morsárjökull \\ Öræfajökull ${ }^{9}$
}

Name of detached glacier

Saudhamarstindur

${ }^{1}$ Pálsson (unpublished) used the name Klofajökull in preference to Vatnajökull, although the latter is the accepted name today. Other place-names of outlet glaciers shown on his 1794 map of Klofajökull were as follows: Skeiðarárjökull, Síoujökull, Skaptárjökull (entire western margin), Dýngjujökull, Brúarjökull, Fljótsdalsjökull (north-eastern margin), Lónjökull (north-eastern part of south-eastern margin), Hornafjarðarjöklar (middle part of south-eastern margin), and Breiðamerkrjökull (south-western part of south-eastern margin), and Øræfajökull. Some of these place-names have survived to the present; others have become obsolete.

${ }^{2}$ Some twentieth century maps show the name Súlujökull for the south-western part of Skeidarárjökull. Súlujökull has now been dropped as a place-name (personal communication from S. Rist, 1986).

${ }^{3}$ Thoroddsen (1892) applied the name Sídujökull collectively to the following three outlet glaciers in south-western Vatnajökull: Sidujökull, Skaftárjökull, and Tungnaárjökull.

${ }^{4}$ Axarjökull.

${ }^{5}$ Some twentieth century maps use the name Svinafellsjökull for the south-western part of Hoffellsjökull. Because of confusion with an outlet glacier of the same name from the western side of Öræfajökull, it has been replaced by the name Hoffellsjökull vestri (personal communication from S. Rist, 1986).

${ }^{6}$ Sultartungujökull; Eyvindstungnakollur.

${ }^{7}$ Fellsjökull; Birnujökull.

${ }^{8}$ Sigbjarnarson (1971) subdivided Breiðamerkurjökull into three parts: Mávabyggdajökull on the west, Esjuf jallajökull in the center, and Norðlingalædarjökull on the east. Rist (personal communication, 1986) stated that these separate parts of Breioamerkurjökull do not really exist as independent glaciers; he prefers that they be referred to as ice "currents": Mávabyggdastraumur, Esjuf jallastraumur, and Nordlingalædarstraumur.

${ }^{9}$ Öræfajökull is not a true outlet glacier. It is a separate ice cap within the southern margin of Vatnajökull, from which 11 outlet glaciers (26-36) originate.

${ }^{10} \mathrm{Hoffellsdalsjökull.}$

caldera (Björnsson 1975, Tómasson 1975) or, less frequently, from volcanic activity (Björnsson and Kristmannsdóttir 1984, Grönvold and Jóhannesson 1984). The surface manifestation on Vatnajökull of subglacial geothermal and (or) intrusive volcanic activity is often in the form of collapse cauldrons (cone-shaped, concentric fault-bounded depressions) in the ice-cap surface, of which the two collapse cauldrons northwest of Grimsvötn are the most prominent at present. Both of these depressions are the source of periodic jökulhlaups on the south-western margin of Vatnajökull, down the valley of Skaftá (Thorarinsson and Rist 1955, Björnsson 1983). According to Thorarinsson and others (1974), the easternmost cauldron first appeared in 1955; according to Björnsson (1983), the westernmost cauldron was first noted in 1971 .

\section{LANDSAT}

Landsat images, especially those acquired during 1973, have proven to be the most valuable of all the Landsat images acquired of Iceland between 1972 and 1986, in terms of providing new information about the regional volcanic geomorphology and tectonics of the terrane beneath Vatnajökull (Figs 3 and 4) (Thorarinsson and others 1974). Although the basic image initially used for the geomorphic analysis of the surface of Vatnajökull was partially cloudcovered and acquired at a solar elevation angle of only $7^{\circ}$ on 31 January (1192-12084) (Fig.3) (Thorarinsson and others 1974), special digital processing of the 22 September 1973 image (1426-12070) (Fig.4) provides essentially the same information for the entire ice cap. On the 1973 winter image, the northern margin and some of the eastern and 
south-eastern parts of Vatnajökull are obscured by clouds; the 1973 late summer image is cloud-free. Image maps at a scale of 1:500 000 have been published for both the winter image (US Geological Survey 1977[a]) and the summer image (US Geological Survey 1976) of Vatnajökull.

Although the low Sun angle 1973 winter image provided the best information about the surface morphology of Vatnajökull, the digitally enhanced, cloud-free late summer image was more valuable for glaciological studies, because it was fortuitously acquired at the approximate end of the 1973 melt season. Delineation of the margin of the ice cap, surface ice divides, and the transient snow line (Fig.2A, B) can be easily accomplished from the image (Fig.4). Special digital image processing of the late summer image also permits delineation of the ice facies of the ablation area and the slush zone and wet-snow facies/percolation facies of the accumulation area of Vatnajökull (Figs 2B and 5). The terminology associated with the concept of glacier facies will be defined and discussed in a later section of this paper. Münzer and Bodechtel (1980) also experimented with various digital image-processing techniques on the fall and winter 1973 images of Vatnajökull to analyze the surface expression of subglacial topography and to plot lineaments.

\section{Digital image-enhancement methods}

Fig. 3 is a standard black-and-white print of Vatnajökull produced from a multi-spectral scanner (MSS) band $7,70 \mathrm{~mm}$ negative processed by an electron-beam image recorder (EBIR). The Landsat 1 image was acquired at a very low solar elevation angle on 31 January 1973. Michael J. Abrams (Jet Propulsion Laboratory, California Institute of Technology) prepared a series of digitally enhanced images from computer-compatible tape (CCT) data, including linear stretches of the optimum range of digital numbers (DNs) of each of the four MSS bands and bi-band ratios of several band combinations. None of these digitally processed data, however, added any new information about the surface morphology other than that which was already evident on the conventionally processed MSS band 7 EBIR image.

Low Sun angle images of snow-covered surfaces, such as Fig.3, enable subtle morphological features to be recorded by the sensors of the Landsat MSS system. This is the result of differential illumination produced by slight changes in slope orientation, especially those at right-angles to the solar azimuth of $162^{\circ}$. At higher Sun angles, morphological and spectral information is of ten lost on snow-covered glaciers because of saturation of the MSS detectors (Ferrigno and Williams 1983, Dowdeswell and McIntyre 1986). An analysis of the 31 January 1973 image of Vatnajökull (Fig.3) yielded considerable information about the regional structural, volcanic, and tectonic setting of the terrane under the ice cap (Thorarinsson and others 1974, Williams and Thorarinsson 1974). Fig. 3 was especially useful in plotting the probable location of surface ice divides (see Fig.2A and $\mathrm{B})$, calderas, collapse cauldrons, and north-east-trending surface features in the western part of Vatnajökull.

Fig. 4 is a digitally enhanced Landsat 1 MSS false-color composite, cloud-free image (bands 4, 5, and 7) of Vatnajökull acquired on 22 September 1973. It was custom processed by Lincoln Perry at the EROS Data Center of the US Geological Survey. A series of standard digital image-processing techniques was applied to all four MSS bands: radiometric restoration (also called destriping), edge enhancement, synthetic line generation, sampling geometric restoration, Earth rotation correction, and detector misregistration correction (US Geological Survey, 1977[b]). Perry also employed a triple piecewise linear-stretch (contrast-enhancement) technique on the three groups of brightness ranges on the Vatnajökull image which were identified from computer-generated histograms of the DNs of each of the three MSS bands $(4,5$, and 7$)$ : highly reflective snow, medium-reflective vegetation, and lowreflective basalt flows, deep water, and outwash plains (sandar). Each of these three groups of reflectance was independently stretched linearly over a specific DN interval to capture the full brightness range (Table II). Each group in each of the three bands was re-combined to create three new digitally enhanced MSS bands. These new digital data
TABLE II. BRIGHTNESS RANGES (RANGE OF DIGITAL NUMBERS (DNS)) BEFORE AND AFTER ADJUSTMENT FOR THE LINEAR CONTRAST STRETCH OF THE THREE REFLECTANCE GROUPS ON THE 22 SEPTEMBER 1973 LANDSAT 1 IMAGE OF VATNAJÖKULL

$\begin{array}{ll}\begin{array}{l}\text { Reflectance } \\ \text { group }\end{array} & \text { DN range before } \\ \text { contrast stretch }\end{array}$

Basalt flows, deep

water, outwash

plains (sandar)

Vegetation, sediment-

laden water, bare

glacier ice

Snow-covered glaciers, $145-255$ snow-pack
Adjusted DN the linear contrast stretch

$32-100$

$0-64$

$65-144$

$100-140$

$140-255$ range used for

were then converted to analog form (film transparency) by a laser beam image recorder (LBIR) and composited on to color film by projecting MSS bands 4, 5, and 7 through yellow, red, and blue filters, respectively, thereby producing the image shown in Fig.4. From a glaciological viewpoint, Perry's achievement was to bring out morphological detail on the highly reflective snow-covered surface of Vatnajökull while still retaining detail in the low-reflectance areas of the ice cap, such as the bare glacier ice and debris-covered termini, and at the same time preserving the standard falsecolor composite image colors. By comparison, virtually all of the morphological information in the snow-covered areas is lost in the EBIR-generated image. The digitally enhanced image (Fig.4) also very nearly recaptures the morphological detail of the ice-cap surface shown on Fig.3, but at a solar elevation angle of $25^{\circ}$, not $7^{\circ}$, thus indicating that this method can be used on scenes acquired under a wide range of solar elevations, as long as a particular MSS band is not saturated.

\section{Glacio-volcanic geomorphology}

The morphological information shown on Fig.4 was used to prepare Fig.2A. Four well-defined, elliptically shaped calderas can be delineated (Thorarinsson and others 1974): one at Grímsvötn, two at Kverkfjöll, and one at Öraefajökull. The $6 \mathrm{~km} \times 4 \mathrm{~km}$ outer rim and the inner $3 \mathrm{~km} \times 2 \mathrm{~km}$ perimeter of the snow- and ice-covered lake on the caldera floor can be delineated at Grimsvötn. The caldera is the source of periodic jökulhlaups which exit to the east before emerging to the south under the terminus of the Skeidarárjökull outlet glacier (Thorarinsson 1953, 1974, Rist 1955, Björnsson 1975, Tómasson 1975, Björnsson and Kristmannsdóttir 1984). Two well-defined calderas both measuring $5 \mathrm{~km} \times 3 \mathrm{~km}$ can be identified in the Kverkfjöll area, either or both being the likely source for jökulhlaups flowing to the north down the valley of the Jökulsá á Fjöllum (Thorarinsson 1950). A linear depression in the icecap surface extends $7 \mathrm{~km}$ to the south-west from the Hveradalur geothermal area into the westernmost caldera, about doubling the previous known linear extent of the geothermal area (Friedman and others 1972). The total thermal yield from Hveradalur and a subglacial geothermal area located approximately $2 \mathrm{~km}$ up-glacier from the terminus of the Kverkfjöll outlet glacier (Kverkjökull) was estimated at $300-540 \times 10^{6} \mathrm{cal} \mathrm{s}^{-1}$ (by Friedman and others 1972) from calculations of areas of thermal activity interpreted from aerial thermographs and photographs, energy estimates of thermal surface drainage from these areas, and energy estimates from temperature and volumetric discharge measurements at the thermal stream emanating from the terminus of Kverkjökull. The extension under the ice cap to the south could raise this total to as much as $1 \times 10^{7} \mathrm{cal} \mathrm{s}^{-1}$, if the thermal output is commensurate with the areal increase. Indistinct linear features (dotted lines on 
Fig.2A) on the ice-cap surface extend another $14 \mathrm{~km}$ to the south-west from the westernmost caldera towards the Grímsvötn caldera.

Approximately 10 and $14 \mathrm{~km}$ north-west of the western margin of the floor of the caldera in Grimsvötn, respectively, are large $(2 \mathrm{~km}$ diameter $)$ and small $(1 \mathrm{~km}$ diameter) cauldrons, the result of subglacial geothermal and (or) intrusive volcanic activity at the base of approximately $500 \mathrm{~m}$ of ice (Eythórsson 1951, Björnsson 1986[a], [b]). From the larger cauldron a $5 \mathrm{~km}$ long sinuous depression extends to the south-west; a $2 \mathrm{~km}$ long depression also extends to the south-west from the smaller cauldron. The channel-like depressions are the probable morphological expressions on the ice-cap surface of the initial part of the sinuous subglacial cavities of water courses which periodically conduct melt water from the geothermal and (or) intrusive volcanic activity beneath the cauldrons to the beginning of the subaerial part of Skaftá river valley at the terminus of Skaftárjökull (Thorarinsson and Rist 1955). Rist (Thorarinsson and Rist 1955) calculated the total volume of water discharged from the September 1955 Skaftárhlaup at $226 \times 10^{6} \mathrm{~m}^{3} \pm 45 \times 10^{6} \mathrm{~m}^{3}$, approximately equivalent in volume to the largest cauldron. The dotted lines on Fig. 2A show linear features on the surface of the ice cap which are the subdued surface expression of subglacial north-east-trending móberg (palagonite) ridges, so strongly expressed south-west of the Vatnajökull margin on Fig.3. Melt water that produces jökulhlaups on the Skaftá (Björnsson 1978[a]) are constrained to flow in a south-westerly direction because of the subglacial orientation of the móberg ridges (Thorarinsson and Rist 1955 , Björnsson 1986[b]). Details of the subglacial morphology in this part of Vatnajökull have been well defined by analysis of data from radio echo-sounding surveys (Björnsson 1978 [b], 1986[a], [b]).

A well-defined $3 \mathrm{~km} \times 2 \mathrm{~km}$ caldera can also be delineated in the summit area of Öraefajökull. A subglacial caldera, with dimensions similar to those at Kverkfjöll, is concealed at Bárdarbunga. Another subglacial, extinct(?) volcano is partially exposed at Esjufjöll with an indistinct $5 \mathrm{~km} \times 3 \mathrm{~km}$ caldera visible north-east of Snaehetta. The eastern part of Vatnajökull apparently conceals another extinct(?) volcano at Grendill, with a possible eroded summit caldera having dimensions similar to the one at Öraefajökull.

\section{Glaciology}

\section{Surface morphology}

On Fig.2A, the probable locations of surface ice divides are delineated north of Grimsvötn, including one branch towards Kverkfjöll (Kverkfjallahryggur) and another towards Esjufjöll. Other probable divides are mapped at Snaehetta, transverse to Nordlingalaegd, at Breidabunga, and another extends south-west from Grendill. Dowdeswell (unpublished) delineated surface ice divides on the Nordaustlandet ice caps of Svalbard from Landsat images. No attempt was made to delineate the approximate boundaries between outlet glaciers on the basis on the surface ice divides, such as was done by Dowdeswell and Drewry (1985) in Svalbard, because of the complex character of Vatnajökull with its 38 named outlet glaciers and its variable subglacial volcanic morphology. Comprehensive radio echo-sounding surveys, such as those of Björnsson (1986[a], [b]) will be a necessary part of delineating the drainage-basin boundaries for each outlet glacier. The margin of Vatnajökull, shown on Fig. 2A which was determined from Fig.4, was used to compile an inventory of the 38 outlet glaciers, one intra-ice-cap ice cap (Öraefajökull), and two detached glaciers (Table I), and to calculate the area of the ice cap $\left(8300 \mathrm{~km}^{2}\right)$. As was already established in the work on Langjökull (Fig.1), Landsat is an excellent source for compiling inventories of large ice masses, especially ice caps and outlet glaciers (Williams 1986). The geographic place-names of the outlet and detached glaciers of Vatnajökull are derived from maps published by the Iceland Geodetic Survey and from maps included in articles published in Jökull and other scientific publications with corrections furnished by Sigurjón Rist (personal communication 1986).

\section{Glacier facies}

The concept of glacier facies was developed by Benson (1959, 1961, 1962) and Müller (1962). Benson's original concept was modified somewhat in subsequent papers (Benson 1967, Benson and Motyka [1979]). In the discussion of glacier facies which follows, however, the latest published work by Benson (Benson and Motyka [1979]) and the work by Müller (1962) are used.

Benson and Motyka ([1979]) divided a glacier into an ablation area and an accumulation area; the dividing line between the two areas represents the equilibrium line. The equilibrium line also represents the down-glacier boundary of the superimposed ice zone. Up-glacier from the equilibrium line is the snow line. The bare glacier ice of the ablation area and the exposed part of the superimposed ice zone between the equilibrium line and the snow line are collectively referred to as the ice facies. Up-glacier from the snow line are the wet-snow facies, the percolation facies, and the dry-snow facies, separated by the wet-snow line and the dry-snow line, respectively. Müller (1962) developed a similar scheme but he subdivided the wet-snow facies and the percolation facies of Benson into three zones up-glacier from the annual snow line: slush zone, percolation zone $B$, and percolation zone $A$, with a slush limit defining the up-glacier boundary of the slush zone and percolation zone $B$.

By special digital image-processing techniques, it appears possible to spectrally delineate some aspects of glacier facies on Landsat images of glaciers acquired during the ablation season (in particular the ice facies, transient snow line, slush zone, wet-snow facies/percolation facies, and possibly the dry-snow facies, although the latter remains to be established). Fig.5 is a digitally enhanced Landsat 1 MSS false-color composite, cloud-free image (bands 4, 5, and 7) of Vatnajökull acquired on 22 September 1973 (processed by Michael J. Abrams from the same CCTs used to produce Fig.4 (Soha and others 1976, Williams and others 1977)). The image was separated into three reflectance zones: dark (deep water), medium (land including vegetation), and bright (snow), the three zones being originally defined by histograms. Each of these zones was linearly stretched in each of the four MSS bands over the full dynamic range for each band, 0-255 DNs for MSS bands 4, 5, and 6, 0-127 DNs for MSS band 7. Unlike Fig. 4 , in which the resulting image retained normal false-color image colors, the projection of the fully stretched MSS bands 4,5 , and 7 through yellow, red, and blue filters, respectively, yielded markedly different colors (Soha and others 1976, personal communication from Michael J. Abrams).

Fig.5 shows the position of the transient snow line on Vatnajökull at $12.07 \mathrm{~h}$ GMT (local Icelandic time) on 22 September 1973. A review of all Landsat images of Vatnajökull acquired in late August or September indicates that the transient snow line on the 22 September 1973 image is probably at its highest altitude. The elevation of the snow line varies around Vatnajökull (Fig.2B), being higher in the north because of less precipitation (Eythorsson 1960, Björnsson 1980[b]). On 22 September 1973, the "snow line" generally paralleled the $1000 \mathrm{~m}$ contour and of ten conformed to it on several outlet glaciers; on the southern margins, the "snow line" is generally lower than $1000 \mathrm{~m}$, descending to about $700 \mathrm{~m}$ on the terminus of Skálafellsjökull; on the northern margin, the snow line is above $1000 \mathrm{~m}$, reaching $1300 \mathrm{~m}$ or more on the north-west slope of Bárdarbunga, around Kverkfjöll, and on the north slope of the area around Grendill.

Fig.2B, a cross-section along $\mathrm{A}-\mathrm{A}^{\prime}$ on Fig.2A, a distance of $123.5 \mathrm{~km}$ from the terminus of Sídujökull in south-western Vatnajökull to the terminus of Brúarjökull on the northern part of the ice cap, shows the snow line at about $900 \mathrm{~m}$ on the former and about $1150 \mathrm{~m}$ on the latter. The planimetric map position of the "snow line" on 22 September 1973, derived from the Landsat imagery, for the entire ice cap is shown as a heavy dashed line on Fig.2A. Sídujökull and Brúarjökull are classified as surging glaciers, and both surged in $1963-64,0.5 \mathrm{~km}$ and $8.0 \mathrm{~km}$, respectively (Thorarinsson 1969). The position of the terminus of Brúarjökull in 1936 is shown by an arrow, approximately $6 \mathrm{~km}$ further south than its position on 22 September 1973. 
Also on Fig.2B, I have shown by arrows the position of the up-glacier edge of the slush zone on Sidujökull and Brúarjökull at $1000 \mathrm{~m}$ and $1200 \mathrm{~m}$, respectively. The positions of these arrows on the cross-section were determined by analysis of the color patterns on Fig.5.

The type of computer-enhanced color image shown in Fig.5 appears to provide a good correlation of spectral variations on the surface of Vatnajökull, with the ice facies of the ablation area and some of the facies of the accumulation area of a temperate glacier. On Vatnajökull, the colors apparently correlate as follows: ice facies (ablation area and superimposed ice zone of the accumulation area): light blue, bare glacier ice; orange, concentration of supraglacial debris (on the surface of the glacier) or englacial material (within the glacier; for example, "dirty" ice versus clean ice). According to Benson and Motyka ([1979]), the ice facies includes the entire ablation area and extends into the accumulation area as a superimposed ice zone (if one is present), between the equilibrium line (boundary between the ablation area and the accumulation area) and the snow line, and also extends beneath the wet-snow facies. It is probably not possible to differentiate between the spectral signatures of bare glacier ice of the ablation area and the exposed part of the superimposed ice zone of the accumulation area, which is also bare glacier ice. On Fig. 2B all bare glacier ice is shown as ice facies. It is not absolutely certain what the orange color represents. It may be a concentration of dirt cones, other surficial debris, or englacial material in the ice facies; field spectra and observations are obviously needed to confirm or reject these conclusions. Laboratory studies of ice suggest that small amounts $(\sim 1 \%$ or less) or particulate matter can reduce the reflectance at $0.55 \mu \mathrm{m}$ (Landsat MSS band 4 is $0.50-0.60 \mu \mathrm{m}$ ) by $50 \%$ or more (Clark 1982). Perhaps the presence of englacial or supraglacial particulate matter is the explanation for the orange color within some parts of the ice facies. Accumulation area: black, slush zone; dark to light gray, wet-snow facies/percolation facies. The black color does apparently correspond with the slush zone. It is a relatively narrow zone on the steeper outlet glaciers (a few kilometers wide) but much wider on gently sloping glaciers, such as on Brúarjökull and Dyngjujökull, where the slush zone can extend for more than $10 \mathrm{~km}$. Above the up-glacier boundary of the slush zone (Fig.2B) is the wet-snow facies which grades further up-glacier into the percolation facies.

It is doubtful whether a dry-snow facies of the accumulation area exists on Vatnajökull, except perhaps at the two highest elevations at Bardarbunga $(2000 \mathrm{~m})$ and Öraefajökull (2119 m). According to Einarsson (1976), during July, the warmest month in Iceland, only two small areas around the two highest parts of Vatnajökull lie within the $0{ }^{\circ} \mathrm{C}$ isotherm of mean monthly temperature. Because of the absence of permanent year-round weather stations on Vatnajökull, the isotherms on the ice cap are calculated from the average adiabatic lapse-rate in Iceland, 0.067 $\operatorname{deg} \mathrm{km}^{-1}$, using interior highland weather stations, such as that at the Mödrudalur farm about $65 \mathrm{~km}$ north of Brúarjökull, as the basis for extrapolation (personal communication from Trausti Jónsson, 1986). Because of slope orientation away from the Sun (solar azimuth of $164^{\circ}$ ), the lighter gray areas on the ice cap are probably the result of this aspect difference in snow reflectance rather than the snow being dry. In all likelihood, the entire ice cap above the up-glacier edge of the slush zone is in the wet-snow facies/percolation facies (Figs 2B and 5), although it is probably not possible to differentiate between the wet-snow facies and the percolation facies solely on the basis of spectral information from the snow-covered surface. The two facies are therefore shown together.

Østrem (1975) showed how the specific mass balance for several Scandinavian glaciers can be determined remotely (on satellite images or aerial photographs) by determining the elevation of the snow line (if it conforms to the equilibrium line) at the end of the melt season. From more than 20 years of mass-balance studies on Nigardsbreen, Norway, Østrem and Haakensen (in press) found a linear relationship between the elevation of the equilibrium line at the end of the ablation season and the specific net mass balance of a glacier. Once the curve is established for a glacier, remote determination of the equilibrium line will give the specific net mass balance for that year. An alternative, although less precise technique is to use the accumulation-area ratio (AAR) to infer whether a given glacier has a positive or negative mass balance (Krimmel and Meier 1975). On the 22 September 1973 image of Vatnajökull (Figs 2B, 4, and 5), the estimated minimum AAR for Vatnajökull was 0.70 , if the position of the snow line on that date was approximately the same as the position of the equilibrium line. Most glaciologists consider a range of $0.5-0.8$ in the $\mathrm{AAR}$ for $\mathrm{b}=0$ to be reasonable for temperate mountain glaciers.

\section{SEASAT}

Seasat Synthetic Aperture Radar (SAR) images of all but the extreme western and north-eastern parts of Iceland were acquired during late summer and early fall of 1978 . Bodechtel and others (1979) were the first to compare Seasat SAR and Landsat MSS images of Iceland to delineate morphologic and tectonic features. Ford and others (1980) published a cursory analysis of a Seasat SAR image (revolution 719; 16 August 1978) and a companion Landsat image (2494-11503; 30 May 1976) of north-central Iceland which included parts of the Dyngjujökull outlet glacier and the Kverkfjöll area. Hunting Geology and Geophysics Ltd (undated) published a 1:500 000 scale Seasat SAR image mosaic of most of Iceland, including all of its glaciers.

An analysis of the Hunting Geology and Geophysics Ltd mosaic does not provide any new or improved information about the morphology of the surface of Vatnajökull when compared with either the January 1973 or digitally processed September 1973 Landsat images. Whether or not morphological features are imaged is strongly influenced by the look-angle of the Seasat SAR with respect to the orientation of the landform during the orbital passes (north-west to south-east or vice versa across Iceland). The two calderas at Kverkfjöll and the linear extension of the Hveradalur geothermal area are prominently imaged. The Grimsvötn caldera is only faintly visible; the caldera on Öraefajökull was not even recorded on Seasat SAR images. Medial moraines are faintly visible as are the two collapse cauldrons and associated sinuous depressions north-west of Grimsvötn. No surface ice divides can be delineated; the pro-glacial lake Graenalon is difficult to delineate, and the various facies of the ablation and accumulation areas were not recorded. The transient snow line is also difficult to delineate over most of the ice cap. Rott (1984[a], [b]) briefly discussed his analysis of a 24 August 1978 Seasat SAR image of Hof sjökull (Fig.1), a small ice cap $\left(915 \mathrm{~km}^{2}\right)$ which lies about $30 \mathrm{~km}$ north-west of Vatnajökull. He found a low radar return from the wetsnow facies at the higher elevations on this ice cap. Radar back-scatter increased down-glacier until it was difficult to discriminate between bare glacier ice and snow in the marginal part of the wet-snow facies. If the back-scatter intensity were identical from bare glacier ice and the slush zone at L-band frequencies, this would explain the difficulty in determining the position of the transient snow line on the L-band SAR image of Vatnajökull.

Neither the Seasat SAR image mosaic of Vatnajökull nor the individual image strips correctly portray the ice cap geometrically; the image cannot be used to produce an accurate planimetric map. In mountainous areas (south-eastern part of Vatnajökull) it is difficult to delineate the termini of the outlet glaciers. Quite the opposite is the case with the lobate outlet glaciers of most of the rest of Vatnajökull. The termini of these outlet glaciers, such as Sídujökull, Dyngjujökull, and Brúarjökull, and associated terminal moraines are clearly shown; their delineation on the Seasat SAR image is superior to the digitally enhanced Landsat MSS image and about equal to a Landsat 3 RBV image (Williams 1979). The combination of improved spatial resolution and the response of two different parts of the electromagnetic spectrum is considered to be the key.

\section{CONCLUSIONS}

Landsat MSS images to date have proven to be the best source of satellite-image data for studying surface morphology and glaciological phenomena, such as glacier 
facies, on the large and complex Vatnajökull ice cap, and in preparing a preliminary inventory of its outlet glaciers (Fig.2A). The successful use of Landsat images to prepare preliminary inventories of some of Iceland's glaciers (Williams 1983[a], [b], 1986) was also used by the Temporary Technical Secretariat for the World Glacier Inventory as the basis for preparing new guidelines for preliminary glacier inventories in polar areas (Scherler 1983). It seems likely that satellite-imaging technology will be increasingly used for some types of glaciological studies, especially the preparation of preliminary inventories and dynamic changes in glacier facies of large ice masses, such as the polar ice sheets and ice caps (Swithinbank 1984, Haeberli 1985, Hall and Martinec 1985, Williams 1985).

Future work on Vatnajökull should include analysis of Système Probatoire d'Observation de la Terre (SPOT) and Landsat Thematic Mapper (TM) images, especially the thermal infra-red and mid-infra-red bands of the latter to determine their applicability to glaciological studies. To correlate better the different spectral reflectance of snow, ice, and morainic debris on the surface of Vatnajökull to the various facies of the ablation and accumulation areas, snow and (or) ice observations, field spectra, and ambient-temperature data need to be collected during traverses of outlet glaciers of the ice cap during the summer melt season.

\section{REFERENCES}

Bauer A 1955 Contribution à la connaissance du Vatnajökull-Islande. Jökull 5: 11-22

Benson C S 1959 Physical investigations on the snow and firn of northwest Greenland 1952, 1953, and 1954. US Army Snow, Ice, and Permafrost Research Establishment. Research Report 26

Benson C S 1961 Stratigraphic studies in the snow and firn of the Greenland ice sheet. Folia Geographica Danica 9 13-37

Benson C S 1962 Stratigraphic studies in the snow and firn of the Greenland ice sheet. US Army Snow, Ice, and Permafrost Research Establishment. Research Report_70

Benson C S 1967 Polar regions snow cover. In Oura $\mathrm{H}$ (ed) Physics of Snow and Ice. International Conference on Low Temperature Science ... 1966 ... Proceedings. Vol 1, Pt 2. [Sapporo], Hokkaido University. Institute of Low Temperature Science: 1039-1063

Benson C S, Motyka R J 1979 Glacier-volcano interactions on Mt. Wrangell, Alaska. University of Alaska. Geophysical Institute. Annual Report, 1977-78: 1-25

Björnsson H 1975 Explanation of jökulhlaups from Grimsvötn, Vatnajökull, Iceland. Jökull 24, 1974: 1-26

Björnsson H 1978[a] Könnun á jöklum med rafsegulbylgjum. Nâttúrufraedingurinn 47(3-4): 184-194

Björnsson H 1978[b] The cause of jökulhlaups in the Skaftá river, Vatnajökull. Jökull 27, 1977: 71-78

Björnsson H 1980[a] Glaciers in Iceland. Jökull 29, 1979: 74-80

Björnsson $\mathrm{H}$ 1980[b] The surface area of glaciers in Iceland. Jökull 28, 1978: 31

Björnsson H 1983 A natural calorimeter at Grimsvötn; an indicator of geothermal and volcanic activity. Jökull 33: 13-18

Björnsson H 1986[a] Delineation of glacier drainage basins on western Vatnajökull. Annals of Glaciology 8: 19-21

Björnsson H 1986[b] Surface and bedrock topography of ice caps in Iceland, mapped by radio echo-sounding. Annals of Glaciology 8: 11-18

Björnsson H, Kristmannsdóttir H 1984 The Grimsvötn geothermal area, Vatnajökull, Iceland. Jökull 34: 24-50

Bodechtel J, Hiller K, Münzer U 1979 Comparison of Seasat and Landsat data of Iceland for qualitative geologic applications. In Seasat-SAR Processor Workshop, Frascati. Proceedings. Paris, European Space Agency: $61-67$

Clark R N 1982 Implications of using broadband photometry for compositional remote sensing of icy objects. Icarus 49(2): 244-257

Dowdeswell $J$ A Unpublished Remote sensing studies of
Svalbard glaciers. (PhD thesis, University of Cambridge, 1984)

Dowdeswell J A, Drewry D J 1985 Place names on the Nordaustlandet ice caps, Svalbard. Polar Record 22(140): 519-523

Dowdeswell J A, McIntyre N F 1986 The saturation of LANDSAT MSS detectors over large ice masses. International Journal of Remote Sensing 7(1): 151-164

Einarsson M A 1976 Vedurfar à Íslandi. Reykjavík, Idunn

Eythórsson J 1945 Jöklaritid. In Eythórsson J (ed) Ferdabók Sveins Pálssonar. Reykjavík, Prentsmidjan Oddi: 423-552

Eythórsson J 1951 Thykkt Vatnajökuls. Jökull 1: 1-6

Eythórsson J 1960 Vatnajökull. Reykjavík, Almenna Bókafélagid

Ferrigno J G, Williams R S Jr 1983 Limitations in the use of Landsat images for mapping and other purposes in snow- and ice-covered regions: Antarctica, Iceland, and Cape Cod, Massachusetts. Proceedings of the Seventeenth International Symposium on Remote Sensing of Environment. Ann Arbor, Environmental Research Institute of Michigan: 335-355

Ford J P and 6 others 1980 Seasat views North America, the Caribbean, and western Europe with imaging radar. Pasadena, CA, Jet Propulsion Laboratory (JPL Publication 80-67)

Friedman J D, Williams R S Jr, Pálmason G, Miller C D 1969 Infrared surveys in Iceland - preliminary report. US Geological Survey. Professional Paper 650-C: C89-C105

Friedman J D, Williams $\mathrm{R} S \mathrm{Jr}$, Thorarinsson S, Pálmason G 1972 Infrared emission from Kverkfjöll subglacial volcanic and geothermal area, Iceland. Jökull 22: 27-43

Grönvold K, Jóhannesson H 1984 Eruption in Grímsvötn 1983; course of events and chemical studies of the tephra. Jökull 34: 1-11

Hall D K, Martinec J 1985 Remote sensing of ice and snow. London, Chapman and Hall

Haeberli W 1985 Global land-ice monitoring: present status and future perspectives. In Glaciers, Ice Sheets, and Sea Level: Effect of a $\mathrm{CO}_{2}$-induced Climatic Change. Report of a workshop held in Seattle, Washington September 13-15, 1984. Washington, DC, United States Department of Energy: 216-231

Helland A 1882 Islaendingen Sveinn Pálssons beskrivelser af islandske vulkaner og braeer. Den Norske Turistforenings Arbok 1882: 19-79

Hunting Geology and Geophysics Undated Seasat-1 radar mosaic (of) Iceland. 1:500000-scale mosaic. Borehamwood, England, Hunting Geology and Geophysics Ltd

Iceland Geodetic Survey 1979 Ísland. 1:750 000-scale map. Reykjavík, Uppdráttur Ferdafélags Íslands

Krimmel R M, Meier M F 1975 Glacier applications of ERTS images. Journal of Glaciology 15(73): 391-402

Müller F 1962 Zonation in the accumulation area of the glaciers of Axel Heiberg Island, N.W.T., Canada. Journal of Glaciology 4(33): 302-311

Münzer U, Bodechtel J 1980 Digitale Verarbeitung von Landsat-Daten in den Eis- und Schneegebieten des Vatnajökulls (Island). Bildmessung und Luftbildwesen 48: 21-28

Østrem G 1975 ERTS data in glaciology - an effort to monitor glacier mass balance from satellite imagery. Journal of Glaciology 15(73): 403-415

Østrem G, Hakensen $\mathrm{N}$ In press Glaciers of Norway. US Geological Survey. Professional Paper

Pálsson S Unpublished Forsög til en physisk, geographisk og historisk Beskrivelse over de islandske Isbjerge i Anledning af en Reise til de fornemste deraf i Aarene 1792-1794 med 4 Situations- og Prospect-Tegninger. "Om isbjerge 1792-1794." Reykjavík, Landsbókasafn Îslands JS 26 Fol (Sveinn Pálsson's handwritten manuscript, which was completed in 1795, was translated from the original Danish to Icelandic by Jón Eythórsson and published by him in 1945. Amund Helland (1882) published (set in type) excerpts from Sveinn Pálsson's original text in Danish, but Helland did not include any maps or drawings included in the original manuscript. Helland also did not publish Part I, Sections 1-10 or Part III, Sections 23-28) 
Rist S 1955 Skeidarárhlaup 1954. Jökull 5: 30-36

Rott H 1984[a] Synthetic aperture radar capabilities for snow and glacier monitoring. Advances in Space Research 4(11): $241-246$

Rott H 1984[b] The analysis of backscattering properties from SAR data of mountain regions. IEEE Journal of Oceanic Engineering OE-9(5): 347-355

Scherler K E 1983 Guidelines for preliminary glacier inventories. Zürich, Swiss Federal Institute of Technology. Temporary Technical Secretariat for the World Glacier Inventory

Sigbjarnarson G 1971 On the recession of Vatnajökull. Jökull 20,1970: 50-61

Soha J M, Gillespie A R, Abrams M J, Madura D P 1976 Computer techniques for geological applications. Proceedings of the Caltech/JPL Conference on Image Processing Technology, Data Sources and Software for Commercial and Scientific Applications. Pasadena, CA, Jet Propulsion Laboratory: 4-1-4-21

Swithinbank C 1984 A distant look at the cryosphere. Advances in Space Research 5(6): 263-274

Thorarinsson S 1950 Jökulhlaup og eldgos á jökulvatnasvædi Jökulsár á Fjöllum. Náttúrufræedingurinn 20(3): 113-133

Thorarinsson S 1953 Some new aspects of the Grimsvötn problem. Journal of Glaciology 2(14): 267-275

Thorarinsson S 1969 Glacier surges in Iceland, with special reference to the surges of Brúarjökull. Canadian Journal of Earth Sciences 6(4, Pt2): 875-882

Thorarinsson S 1974 Vötnin strid. Saga Skeidarárhlaupa og Grímsvatnagosa. Reykjavík, Bókaútgáfa Menningarsjóds

Thorarinsson S, Rist S 1955 Skaftárhlaup i september 1955. Jökull 5: 37-40

Thorarinsson S, Sæmundsson K 1980 Volcanic activity in historical time. Jökull 29, 1979: 29-32

Thorarinsson S, Sæmundsson K, Williams R S Jr 1974 ERTS-1 image of Vatnajökull: analysis of glaciological, structural, and volcanic features. Jökull 23, 1973: 7-17

Thoroddsen Th 1892 Islands Jøkler i Fortid og Nutid. Geografisk Tidskrift 11(5-6), 1891-1892: 111-146

Tómasson H 1975 Grímsvatnahlaup 1972, mechanism and sediment discharge. Jökull 24, 1974: 27-39

US Geological Survey 1976 Vatnajökull, Iceland (fall scene). 1:500000 scale. Reston, VA, US Geological Survey (Landsat Image Format Series N6359W01723. Experimental printing)

US Geological Survey 1977[a] EROS digital image enhancement system (EDIES) fact sheet. Sioux Falls, SD, EROS Data Center

US Geological Survey 1977[b] Vatnajökull, Iceland (winter scene). 1:500000 scale. Reston, VA, US Geological Survey (Landsat Image Format Series N6359W01723. Experimental printing)

Williams R S Jr 1979 Regional geologic mapping using Landsat 3 return beam vidicon images: examples from Iceland and Cape Cod, Massachusetts. Geological Society of America. Abstracts with Programs 11(7): 541

Williams R S Jr 1983[a] Remote sensing of glaciers. In Colwell R N (ed) Manual of remote sensing. Geological applications. Second edition. Falls Church, VA, American Society for Photogrammetry and Remote Sensing: $1852-1866$

Williams R S Jr 1983[b] Satellite glaciology of Iceland. Jökull 33: 3-12

Williams R S Jr 1985 Monitoring the area and volume of ice caps and ice sheets: present and future opportunities using satellite remote-sensing technology. In Glaciers, Ice Sheets, and Sea Level: Effects of a $\mathrm{CO}_{2}$-induced Climatic Change. Report of $a$ workshop held in Seattle, Washington September 13-15, 1984. Washington, DC, United States Department of Energy: 232-240

Williams R S Jr 1986 Glacier inventories of Iceland: evaluation and use of sources of data. Annals of Glaciology 8: 184-191

Williams R S Jr, Thorarinsson S 1974 ERTS-1 image of the Vatnajökull area: general comments. Jökull 23, 1973: 1-6

Williams $\mathrm{R} \quad \mathrm{S} \mathrm{Jr}$, Mecklenburg $\mathrm{T} \mathrm{N}$, Abrams $\mathrm{M} \mathrm{J}$, Gudmundsson B 1977 Conventional vs. computer-enhanced Landsat image maps of Vatnajökull, Iceland. Geological Society of America. Abstracts with Programs 9(7): 1228-1229 